\title{
Гены, определяющие антоциановую пигментацию картофеля Solanum tuberosum L., как мишени для селекции сортов
}

\section{с высокой пищевой ценностью}

\author{
К.В. Стрыгина ${ }^{1 *}$, А.В. Кочетов ${ }^{1}$, Е.К. Хлесткина ${ }^{1,2,3}$ \\ ${ }^{1}$ ФИЦ Институт циитологии и генетики СО РАН, Новосибирск, Россия \\ ${ }^{2}$ Новосибирский государственный университет, Новосибирск, Россия \\ ${ }^{3}$ ФИЦ Всероссийский институт генетических ресурсов растений имени Н.И. Вавилова (ВИР), \\ Санкт-Петербург, Россия \\ *e-mailpushpandzhali@bionet.nsc.ru
}

Антоцианиновые пигменты представляют собой вторичные метаболиты растений, имеющие множественные биологические функции. Активация синтеза антоцианов происходит с помощью MBW, который формируется факторами транскрипции MYB, bHLH и WD40. Определенные гены и их аллельные варианты, влияющие на фенотип (фиолетовая или красная кожура клубня, фиолетовая или красная мякоть, фиолетовые листья, стебли), еще не идентифицированы. Целью нашего исследования является выявление аллельных различий, лежащих в основе фенотипической вариации по признакам окраски картофеля, и разработка аллельспецифических ДНК-маркеров для будущих программ селекции картофеля.

Информация о известных генах $M Y B$-, $b H L H$ - и $W D 40$-кодирующих данных была использована для разработки аллель-специфических маркеров для анализа регуляторных генов. Диагностические маркеры ДНК были разработаны для каждого из идентифицированных генов и их аллельных вариантов. Используя ОТ-ПЦР для восьми генотипов, отличающихся окраской, мы сравнивали активность некоторых копий генов $M Y B, b H L H$ и $W D 40$. Были выделены регуляторные гены семейств MYB (StAN1, StMYBA1, StMYB113), bHLH (StJAF13 и StbHLH1), WD40 $(S t W D 40)$. Мы показали, что основным регулятором появления антоциановой окраски в листьях и стеблях среди генов, кодирующих факторы МYВ, является StAN1. Экспрессия других генов, кодирующих факторы MYB, а также генов, кодирующих bHLH и WD40, не коррелировала с окраской картофеля.

Таким образом, мы разработали внутригенные маркеры, благодаря которым могут быть обнаружены различия в аллелях StAN1. Однако из-за высокого аллельного разнообразия в этом локусе разработанные маркеры не могли использоваться отдельно для прогнозирования окраски стебля и клубней. Для разработки эффективных маркеров необходим дальнейший анализ нуклеотидных последовательностей и идентификация связи генетических полиморфизмов с уровнем транскрипции. В целом результаты исследования важны для понимания механизмов, определяющих специфику регуляции синтеза антоцианов.

Благодарности: Работа выполнена при финансовой поддержке гранта РНФ № 16-16-04073. 